\title{
DIVERSIDADE, REDES E TERRITÓRIOS DE RESISTÊNCIA E AFIRMAÇÃO NO ESTADO DE SÃO PAULO: uma leitura a partir da Parada LGBTQIAP+
}

\author{
DIVERSITY, NETWORKS AND TERRITORIES OF RESISTANCE AND AFFIRMATION IN \\ THE STATE OF SÃO PAULO: a reading from the LGBTQIAP+ Parade
}

Wilians Ventura Ferreira SOUZA¹, Carlos Alberto FELICIANO²

Artigo recebido em 01/03/2021, aceito em 01/07/2021, publicado em 16/07/2021.

Palavras-chave:
Movimento
LGBTQIAP+;
Parada
LGBTQIAP+;
Diversidade.

Keywords: LGBTQIAP+ Movement; LGBTQIAP+ Stop; Diversity.

\section{RESUMO}

O Movimento LGBTQIAP+ brasileiro e de outras escalas, como 0 de Presidente Prudente $\mathrm{SP}$, possui maneiras de atuar que o diferencia de outros movimentos socioespaciais e socioterritoriais. $O$ trunfo não está na terra, na água, na moradia, ainda que estes espaços perpassem a escala do corpo e da vida. Temos visto o surgimento de Coletivos Sem-Terra que tem pautado a diversidade dentro de seus territórios de luta, apesar disso, é importante afirmar que o Movimento LGBTQIAP+ tem como trunfo a vida em suas infinitas representações e possibilidades. Um corpo é político, assim, um movimento que compõem dada pluralidade de corpos também é político, ele é essencialmente político, isto é, a política é um elemento constitutivo do ser. As Paradas aparecem neste artigo como um tipo de ação essencial do Movimento LGBTQIAP+ paulista. Sabemos que elas, enquanto ação socioespacial e socioterritorial, alteram e provocam mudanças nas dinâmicas das cidades que as realizam, produzem mudanças no cenário nacional e internacional pela sua potente capacidade de penetração nas mais diferentes camadas da sociedade. 0 objetivo deste artigo é discutir a importância dessa ação para a constituição dos movimentos e das redes de movimentos existentes em alguns municípios do Estado de São Paulo. Para alcançarmos o objetivo alvitrado, aplicamos um questionário com 121 pessoas LGBTQIAP+ que participam das Paradas, de movimentos, instituições e organizações que pautam a diversidade sexual e de gênero no Estado de São Paulo, bem como realizamos um levantamento bibliográfico e pesquisas de campo.

\section{ABSTRACT}

The Brazilian LGBTQIAP+ Movement and other scales, such as Presidente Prudente - SP, have ways of acting that differentiates it from other socio-spatial and socioterritorial movements. The trump card is not on earth, water, dwelling, even though these themes permeate the scale of body and life. We have seen the emergence of Landless Collectives that have guided diversity within their fighting territories, despite this, it is important to affirm that the LGBTQIAP+ Movement has as its trump card life in its infinite representations and possibilities. A body is political, so a movement that make up given plurality of bodies is also political, it is essentially political, that is, politics is a constitutive element of being. The Parades appear in this article as a type of essential action of the LGBTQIAP+ Movement in São Paulo.

\footnotetext{
${ }^{1}$ Mestrando e Graduado em Geografia pela Universidade Estadual Paulista "Júlio de Mesquita Filho" - Campus de Presidente Prudente.

2 Doutor em Geografia pela Universidade de São Paulo. Pesquisador III pela Universidade Estadual Paulista e Professor do Programa de PósGraduação em Geografia.
} 
We know that they, as a socio-spatial and socio-territorial action, alter and provoke changes in the dynamics of the cities that carry them out, produce changes in the national and international scenario due to their powerful penetration capacity in the most different layers of society. The aim of this article is to discuss the importance of this action for the constitution of movements and networks of movements existing in some municipalities of the State of São Paulo. To achieve the alvitrado objective, we applied a questionnaire with 121 LGBTQIAP+ people who participate in the Parades, movements, institutions and organizations that guide sexual and gender diversity in the State of São Paulo, as well as conduct a bibliographic survey and field research.

\section{INTRODUÇÃO}

Iniciamos esse tópico com a provocação: a Parada LGBTQIAP+3 é uma ação-resposta ao sistema heteronormativo, heterossexista, monossexista e patriarcal? Ou foi engolido pela sua lógica de exploração, acumulação e comercialização de significados e símbolos do movimento LGBTQIAP+ brasileiro a partir das Paradas e outras tipologias de ação?

A princípio pode parecer uma provocação radical, mas longe disso, pretendemos com este artigo atentar para a seguinte reflexão: os movimentos socioespaciais e socioterritoriais que lutam pela diversidade sexual e de gênero (internacional e nacional) nascem em contextos marcados pela violência e pela ausência de liberdade. Assim, constroem agendas e pautas específicas para cada contexto espacial, territorial e momento histórico. Também sabemos que o movimento se utiliza de ações específicas e que já se consumaram como símbolos internacionais da luta pela diversidade, a exemplo da Parada LGBTQIAP+, realizadas em diferentes escalas e municípios brasileiros. Entretanto, na contramão desse processo de conquistas e avanços em algumas políticas públicas, principalmente, aquelas centradas nas liberdades individuais, alguns autores, como apresentaremos posteriormente, realizam uma crítica importante acerca do mercado de consumo construído em torno das ações e pautas erigidas historicamente pelo movimento LGBTQIAP+, isto é, sustentam o argumento de que símbolos e imagens que representam o movimento LGBTQIAP+ hoje se inserem em políticas de mercado e consumo para o público do arco-íris (Pink Money). As críticas tecidas ao mercado de consumo construído em torno dos movimentos e das ações coletivas propostas são importantes, mas não reduzem a relevância da luta e das pautas construídas por esses sujeitos em torno da liberdade de seus corpos e vidas.

Antes de adentrarmos especificamente na (des)construção da Parada LGBTQIAP+ enquanto um tipo de ação, representação, disputa espacial/territorial e rede, é importante delinearmos alguns elementos

\footnotetext{
3 Para uma melhor compreensão do texto, adotamos a sigla LGBTQIAP+ (significando Lésbicas, Gays, Bissexuais, Travestis, Transgêneros, Queer, Intersexuais, Assexuais e Pansexuais), que designa um coletivo de sujeitos genericamente concentrados dentro da categoria maior "diversidade sexual".
} 
presentes nas opressões cotidianas que afetam diretamente lésbicas, gays, bissexuais, travestis, transgêneros, queers, intersexuais, assexuais, pansexuais e outras expressões, performances, orientações e identidades não mencionadas, sujeitos estes que são atravessados pelo recorte racial, pelo sexo, gênero, corpo, desejo, cor, classe, entre outras questões que se enovelam e se entrelaçam na construção de um verdadeiro emaranhado que está para além de uma concepção identitária e simplista.

Acetta (2016), Aguião (2016), Amaral (2014), Louro (2020), Ornat (2008) Butler (2003) Bianor (2017) Costa \& Bernardes (2013) e Souza \& Feliciano (2020) realizam um conjunto de discussões que nos permite entender a sexualidade não como um resultado unicamente biológico, mas, erigida a partir dos intercâmbios, relações, interações sociais, culturais e políticas que se dão cotidianamente nos diferentes espaços e territórios ocupados por esses sujeitos.

Para além da compreensão ampla da diversidade sexual e de gênero, a forma/modo como compreendemos o mundo depende de forma geral dos dualismos que são construídos em torno de temas e conceitos, que se apresentam como objetos ou sistemas de crenças opostas. É partindo do desafio de colocar em xeque os dualismos e sua historicidade, isto é, como foram construídos e arquitetados pelo discurso científico, que Fausto-Sterling (2002) realiza uma reflexão em torno de três destes dualismos: sexo/gênero, natureza/criação e real/construído. Assim, "entender como operam raça e gênero - em conjunto e independentemente - nos ajuda a compreender melhor como o social se torna corporificado" (FaustoSterling, 2002, p. 9).

É importante ressaltar que não existe isto ou aquilo, existe sim, uma infinidade de possibilidades, experiências e práticas corporais generificadas, sexualizadas e simbólicas construídas pelos/as sujeitos/as. Dadas práticas são espaciais e territoriais a depender da análise e leitura de determinado pesquisador a partir do arcabouço teórico-conceitual que ele utilizará; neste artigo a leitura estará centrada no tipo de ação engendrada pelos movimentos socioespaciais e socioterritoriais que disputam na atualidade espaços e territórios afirmando e reafirmando suas identidades e corpos enquanto territórios constantemente violados e violentados. É nesse sentido que rotular o que é ser homem, mulher e outras identidades se coloca como uma decisão, social, "podemos utilizar o conhecimento científico para nos ajudar a tomar a decisão, mas só nossas crenças sobre o gênero também afetam o tipo de conhecimento que os cientistas produzem sobre 0 sexo" (Fausto-Sterling, 2002, p. 15).

Foucault (2001) apresenta um conjunto de ideias que nos permite entender que a sociedade ainda requeria alguma forma de disciplina em um capitalismo nascente para controlar a inserção de corpos no maquinário da produção e o ajuste dos fenômenos da população ao processo econômico. A segunda forma de poder sobre os corpos vivos, como aponta Foucault, estaria centrado numa biopolítica da população, essa ideia surgiu no início do século XIX quando os primeiros cientistas sociais começaram a desenvolver os 
métodos estatísticos de levantamentos para supervisionar e administrar nascimentos e mortalidade, o nível da saúde, a expectativa de vida e longevidade. Dessa forma, "ao ajudarem o normal a assumir a precedência em relação ao natural, os médicos também contribuíram para a biopolítica populacional" (Fausto-Sterling, 2002, p. 26).

Ver-se-á a partir de Foucault (2001) que o discurso constrói um conjunto de relações e interações que nos permite entender o que é considerado normal; esse processo marginaliza determinados corpos em detrimento de outros, essa percepção da marginalização, violência e brutalização dos corpos ficará evidente no momento da exposição dos gráficos acerca das respostas dadas pelos 121 sujeitos entrevistados para a construção desse manuscrito. A formulação dicotômica em torno do sexo e gênero é refletida e materializada em nossas vidas como possibilidades fixas, irrefutáveis e imóveis. Um exemplo é o fato de que as pessoas são posicionadas inerentemente como homossexuais ou heterossexuais, homens e mulheres, o fato de ser isto ou aquilo anula completamente outras experiências e vivências sexuais que constituem os sujeitos, assim, a sexualidade é absurdamente simplificada.

Marglin (1980), Hirata (1995; 2010; 2015), Hirata \& Kergoat (2007) e Saffioti (1976; 2005) destacam a divisão social e sexual do trabalho como estruturas marcantes dessa imposição, ocorrendo a diferenciação e atribuição de atividades específicas para homens e mulheres, injunção construída a partir de valores e parâmetros socialmente referenciados. Dessa forma, a sexualidade humana passa a ser embasada socialmente, destarte, podemos partir de uma discussão acerca das imposições sexuais e de gênero direcionadas aos sujeitos, bem como as respostas que os movimentos socioespaciais e socioterritoriais, coletivos e sujeitos organizados, ou não, constroem nesse cenário dialético, conflituoso e paradoxal.

Foucault (1988) demonstra que no Ocidente se formou uma ciência sexual que produz discursos de verdade sobre a sexualidade. Desta maneira, debater sexualidade e temas correlatos nos ajuda a entender a formação dos movimentos que lutam pela diversidade sexual e de gênero em diferentes escalas. Foucault (2001) compreende a sexualidade enquanto uma "tecnologia de poder". O discurso em torno da sexualidade passa a exercer um poder sobrepujante e posicionar a heterossexualidade como padrão de normalidade. Essa reflexão se inicia quando o autor ministra o curso "Os anormais" no Collège de France em 1974 e 1975. Naquele momento Foucault (2001) construiu uma nova proposta por meio da abordagem da medicalização tratando inicialmente da sexualidade enquanto dispositivo e representação.

Assim sendo, identificamos esse campo/objeto de investigação como um tema em potencial e, que deve, principalmente, ser explorado pela Geografia e outras humanidades, buscando compreender suas relações e interações socioespaciais e socioterritoriais. Sabemos, portanto, que esses sujeitos são violentamente atingidos pelas estruturas de opressão já mencionadas, entretanto, pelo que ou por qual motivo esses sujeitos se organizam em uma ação como a Parada LGBTQIAP+? Por que acreditar que uma ação 
pontual, efêmera e nem sempre bem vista por algumas alas da sociedade tem a capacidade de transformar dada realidade? Essas são algumas das questões que nos provocam.

O objetivo deste artigo é discutir um conjunto de conceitos e teorias ${ }^{4}$ que vêm sendo desenvolvidas por uma ampla rede de pesquisadores e pesquisadoras em âmbito nacional e internacional dentro do conhecimento geográfico, dado coletivo engloba o Núcleo de Estudos, Pesquisas e Projetos de Reforma Agrária - NERA e a REDE DATALUTA. As interpretações, análises e reflexões em torno dos movimentos socioespaciais e socioterritoriais que atuam no espaço urbano, agrário, águas e florestas, potencializaram, sem dúvida, as leituras acerca dos conceitos de espaço e território a partir de uma perspectiva relacional e dialética; o corpo é território, assim como a construção do conhecimento é território. Nesse sentido, avaliaremos e discutiremos a importância da Parada LGBTQIAP+ e ações congêneres para a constituição dos movimentos e das redes de movimentos socioespaciais e socioterritoriais existentes em alguns municípios do Estado de São Paulo.

Buscaremos evidenciar todas essas ações e relações promovidas por esses movimentos e sujeitos que disputam diferentes espaços e territórios desde uma perspectiva coletiva através da realização da Parada LGBTQIAP+, até uma perspectiva individual a partir da luta pela liberdade de seus corpos enquanto territórios violados por outros sujeitos ou até mesmo pelo Estado. Este artigo envolve a realização de entrevistas semiestruturadas, trabalhos de campo, construção de espaços de diálogo e discussão (colóquios, encontros e grupos focais) e questionários que concentram informações relevantes em torno das práticas espaciais dos sujeitos que frequentam e participam das Paradas em Presidente Prudente-SP e em outros municípios do Estado de São Paulo - SP.

O questionário aplicado a esses sujeitos é uma pequena etapa da pesquisa, mas uma importante metodologia aplicada. Essa ferramenta potencializou a nossa compreensão em torno dos movimentos socioespaciais e socioterritoriais (Halvorsen, Fernandes \& Torres, 2019; 2021) e de suas ações (paradas, mesas, ações, espaços de afirmação, etc.). Pudemos, a partir das centenas de respostas captadas, encontrar algumas aproximações entre as práticas espaciais, espaços de afeto, espaços de medo, espaços de construção social-política, entre outras percepções, que estarão cada vez mais evidentes a partir da exposição dos dados e das informações tratadas e trabalhadas.

O questionário consiste em um instrumento de coleta de informação, seja ela qualitativa ou quantitativa (Triviños, 1987). A partir dos nossos objetivos e intencionalidades construímos um questionário com perguntas abertas e fechadas, que possui ao todo 34 perguntas, sendo 10 questões centradas em

\footnotetext{
${ }^{4}$ Os conceitos que serão diretamente trabalhos e que vêm sendo debatidos e desenvolvidos por essa rede de pesquisadores no projeto intitulado "Movimentos Socioterritoriais em perspectiva comparativa" financiado pela Coordenação de Aperfeiçoamento de Pessoal de Nível Superior (CAPES) e que envolve vários países do mundo, sobretudo, Argentina, Brasil, Estados Unidos, Austrália e Reino Unido, são: espaço, território, movimentos socioespaciais e socioterritoriais.
} 
informações gerais (nome, cidade, religião, etc.), 5 perguntas sobre a relação dos sujeitos com espaços de afirmação e segurança em contraposição aos espaços de medo, 2 questões sobre a participação política (direta) dos sujeitos e, por fim, 17 questões sobre a participação, percepção e ideia que os sujeitos tem e construíram das Paradas LGBTQIAP+ que participaram, bem como do deslocamento de alguns sujeitos para outras cidades e a importante relação/hierarquia que algumas cidades possuem em relação as outras a partir da construção desse evento.

O questionário foi construído virtualmente através da utilização da plataforma Google Formulários respeitando as normas de isolamento social devido à pandemia do Novo Coronavírus. O Google Formulários é uma ferramenta de gerenciamento de pesquisas gratuita que possibilita a construção de questionários e produtos similares.

\section{A PARADA LGBTQIAP+: AS POTENCIALIDADES E FRAGILIDADES A PARTIR DA PERCEPÇÃO DOS SUJEITOS SOCIAIS}

É evidente que a Parada é uma resposta. Sabemos que essa ação foi construída nos moldes de uma manifestação, sobretudo, política e reivindicatória, assim, entendemos essa ação como uma outra possibilidade. Veremos que a Parada, nas últimas décadas, alcançou uma inquestionável visibilidade e manifestação socioespacial em centenas de cidades brasileiras.

O trabalho de Ortolano (2015) realiza uma leitura em torno da análise psicopolítica e das diferentes possibilidades de se compreender a sexualidade e os direitos humanos. Dessa forma, a Parada LGBTQIAP+ revela-se como ação central para dada compreensão, já que, a partir dela, diferentes ações acontecem em torno de vários temas e assuntos. É nesse sentido que as Paradas LGBTQIAP+ realizadas em diferentes municípios do Estado de São Paulo produzem e promovem territórios de afirmação e resistência; isso ficará mais evidente nos gráficos construídos acerca das respostas dadas pelos participantes da pesquisa.

Inicialmente, já é possível compreender uma das intencionalidades de Ortolano (2015), que está centrada em analisar o conteúdo psicopolítico explicito ou não da Parada. Dentro de todas as expressões existentes nesta ação que possui relevante representatividade, o autor realiza alguns questionamentos que perpassam a sexualidade e direitos humanos, ou seja, como uma ação como a Parada pode influenciar na construção de cenários e espaços de ação, institucionais ou não, políticos ou não, etc.

A multiplicidade de expressões, de performatividade e de gênero vividas pelos/as atores/atrizes sociais que fazem as paradas do Orgulho LGBT nos leva a pensar no modo como essa pluralidade interfere nas relações sociais, nas dinâmicas dos movimentos homossexuais e na produção de uma agenda política cujo centro está na sexualidade enquanto um direito humano. (Ortolano, 2015, p. 19). 
As ações expressas pelos/as sujeitos militantes LGBTQIAP+ ora se aproximam, ora se antagonizam. Isso nos leva a pensar quais seriam os pontos e pautas que aproximariam o movimento, de fato, numa luta coletiva e uníssona, ao mesmo tempo, quais seriam os pontos e pautas que afastariam uns dos outros, tornando o processo político mais dissidente. Sem dúvida, um dos pontos mais centrais para a compreensão da luta coletiva pautada por diferentes sujeitos, coletivos, movimentos e instituições está posicionado no fato do Brasil ser um país que marcadamente viola o direito básico de pessoas LGBTQIAP+.

Todas essas estruturas e imposições contribuem para o acirramento e tensionamento de um discurso que posiciona esses sujeitos no campo da "nadificação", do alvo a ser derrubado, do subversivo, do pecado, daquilo que merece ser escarnecido e combatido. Dentro deste cenário de violência e brutalização, destacamos alguns números em torno dos crimes de ódio contra LGBTQIAP+ no Brasil em diferentes contextos e realidades.

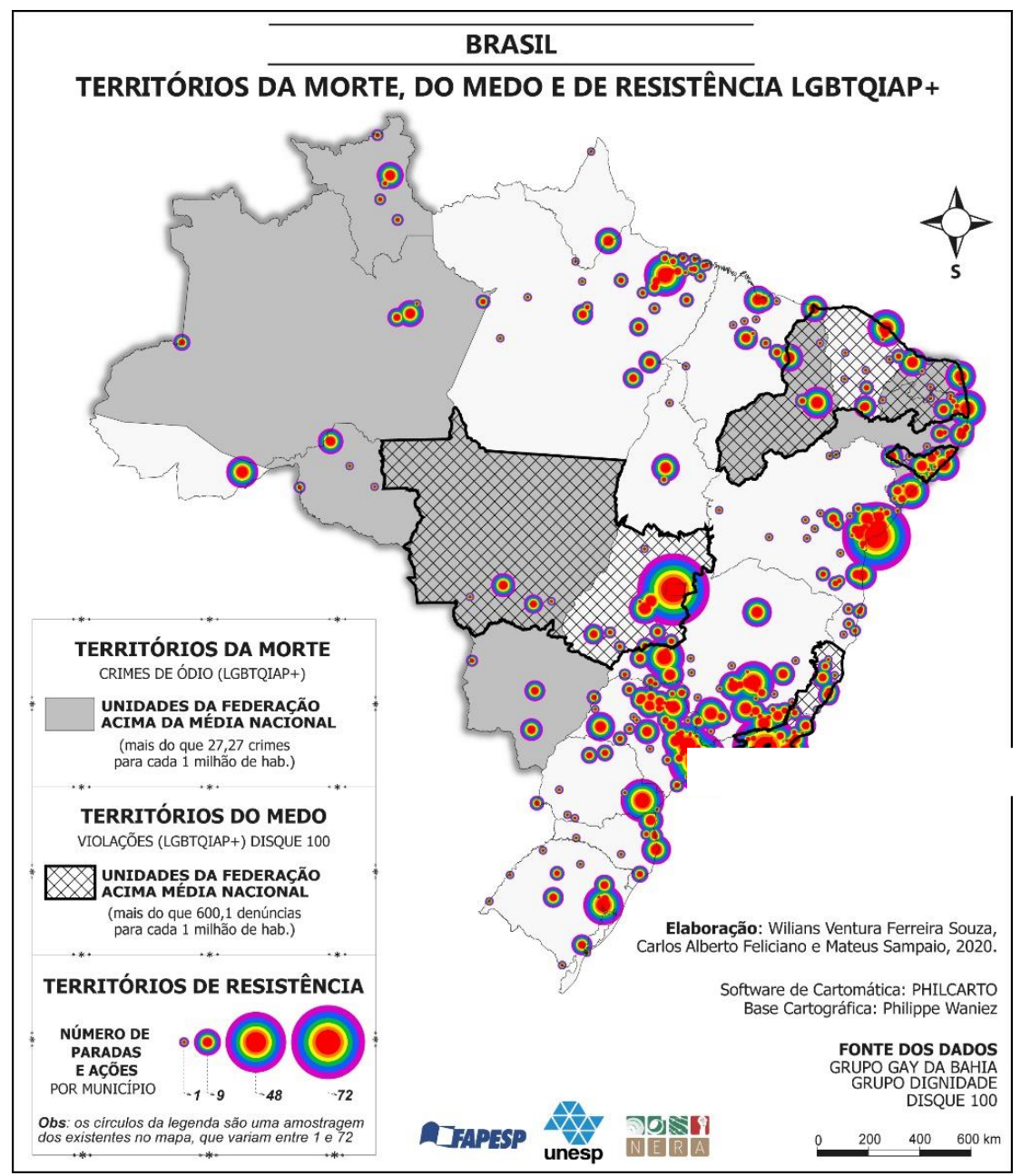

Figura 1 - Territórios da Morte, do Medo e Resistência LGBTQIAP+ no Brasi Fonte : Grupo Gay da Bahia ; Ministério dos Direitos Humanos ; Grupo Dignidade, 2021. Organização : Os autores, 2021. 
O mapa-síntese "Brasil: territórios da morte, do medo e da resistência LGBTQIAP+" representa um avanço significativo na compreensão das mortes e processos de violação, bem como no surgimento, permanência e continuidade das resistências dos sujeitos sociais que emergem para enfrentar e combater as práticas de violência. Assim sendo, as ações surgem como resposta à violência e aos processos de violação direcionados a esses sujeitos. Desta maneira, esses sujeitos saem as ruas reivindicando educação, liberdade, saúde, cultura, trabalho, cidadania, etc.

Os Territórios de Resistência são apresentados no mapa (Figura 1) por círculos em cores do arco-íris. Quanto maior o círculo, maior o número de eventos em defesa dos direitos e do orgulho LGBTQIAP+ ocorridos e registrados pelo Grupo Dignidade. Esta informação é apresentada em nível municipal e representa a somatória dos eventos ocorridos entre os anos de 2006 e 2019 (exceto para 2015, 2016 e 2017 em que há a ausência dos dados).

Os Territórios do Medo são representados por uma textura de hachura (quadriculado). Esta informação é apresentada em nível estadual. Os Estados com essa textura são os que apresentaram uma quantidade de denúncias sobre violações (índice para cada 100 mil habitantes) acima da média nacional entre os anos de 2011 e 2017. Estes dados foram registrados pelo Disque 100. Estados sem hachuras também possuem violações, porém em quantidade abaixo da média nacional. O "Disque 100" utilizado para expressar os Territórios do Medo se utiliza de categorias para apontar processos violadores que ocorrem contra pessoas LGBTQIAP+. Entende-se por violação: abuso financeiro, econômico e violência patrimonial, discriminação, negligência, tortura e outros tratamentos ou penas cruéis, trabalho escravo, tráfico de pessoas, violência institucional, violência física, violência psicológica, violência sexual e outros (como o cyberbullying).

Os Territórios da Morte são apresentados no mapa na cor cinza. Esta informação também é apresentada em nível estadual. Os Estados com essa coloração são os que apresentaram uma quantidade de mortes (índice por milhão de habitantes) acima da média nacional entre os anos de 2000 e 2019 (exceto para 2003, 2006 e 2007). Estes dados foram registrados pelo Grupo Gay da Bahia. Estados não pintados de cinza também possuem este tipo de crime de ódio, mas em quantidade abaixo da média nacional.

Toda essa relação qualitativa existente entre as variáveis trabalhadas no mapa (Figura 1) dialoga diretamente com as respostas dadas pelos sujeitos que participaram da pesquisa; essa relação pode ser percebida quando os sujeitos revelam os motivos de ocuparem as ruas se utilizando de uma ação como essa quando promovem espaços, reuniões e encontros que visam potencializar a conscientização e discussões sobre a temática, entre outras questões. O ponto chave para a compreensão dos territórios de resistência e afirmação está no fato de possuírem uma enorme ausência de políticas públicas e até mesmo referências do que é ser lésbica, gay, bissexuais, travesti, transexual, transgênero, queer, intersexual, assexual, pansexual, 
etc. Chamamos novamente a atenção para essa relação, os territórios de resistência e afirmação são criados pelos movimentos socioespaciais e socioterritoriais como uma resposta aos territórios da morte e do medo que visam, sobretudo, matar materialmente e simbolicamente determinados corpos. Essa brutalização e assassinato físico e simbólico de pessoas LGBTQIAP+ pode ser compreendido a partir de alguns casos sistematizados pelo Grupo Gay da Bahia (GGB) e a ONG Arte e Política Acontece LGBTI+ de Florianópolis. Tomamos como exemplo um caso de uma travesti de Campinas-SP que foi assassinada e teve seu coração arrancado e guardado debaixo do guarda-roupa do responsável pelo crime, no momento em que o responsável pelo assassinato foi capturado pela polícia ele demonstrava satisfação de ter realizado tal feito e dizia que a vítima "era um demônio". 5

Mesmo trabalhando com três classes territoriais diferentes (Territórios de Resistência, do Medo e da Morte), é importante entendermos que todos os espaços mapeados contêm, em diferentes escalas e proporções, elementos das três tipologias espaciais. Vide por exemplo o caso do Estado do Mato Grosso, que está na tonalidade cinza, possui textura hachurada e apresenta quatro pontos com círculos coloridos. Ou 0 caso do Estado de São Paulo, que não está pintado na tonalidade cinza, não possui textura hachurada e apresenta um grande número de pontos com círculos coloridos. O importante é destacar: tanto Mato Grosso quanto São Paulo possuem crimes de ódio, violações e atos afirmativos - o que muda é a intensidade.

O discurso assume centralidade e dialoga diretamente com o ideário desses sujeitos que comportam e dão o tom político ao movimento. Assim é "por meio do discurso que se cria acontecimentos e condição existencial em uma realidade simbolicamente produzida" (Ortolano, 2015, p. 19).

Como expresso pelo autor, o espaço atua como um importante conector entre os discursos, ele aproxima diferentes sujeitos possibilitando, assim, uma interação, uma troca de experiências. Dessa forma, como aponta Ortolano (2015, p. 22), "as paradas LGBT representam, assim, um espaço de relevância capaz de congregar a diversidade sexual, a pluralidade de sujeitos e de performatividade".

Os elementos que atrelam a diversidade sexual, suas manifestações e expressões estão intimamente ligados com a garantia dos direitos universais, bem como a liberdade como uma garantia desses direitos. Assim, Bobbio (2004) aponta que os sujeitos são compreendidos de outra maneira, passam a ter seus direitos legitimados e não somente os seus deveres. Tratamos, principalmente, de uma concepção democrática envolvida em elementos que condicionam a paz e o bem-estar. Logo, como aponta Ortolano (2015, p. 73), "os direitos humanos são frutos de processos históricos, logo, a ética que lhe envolve se dá na vigilância sobre a moral que o constitui, a partir dos elementos significativos da época em que são concebidos".

\footnotetext{
5 https://g1.globo.com/sp/campinas-regiao/noticia/2019/01/21/homem-e-preso-em-campinas-apos-matar-e-guardar-coracao-davitima-em-casa.ghtml
} 
Ao conceber nossa leitura em torno dos movimentos socioespaciais e socioterritoriais, é imprescindível que enalteçamos o papel do ideário contido na cartilha de Direitos Humanos, apresentada anteriormente, bem como a sua importância frente aos ataques direcionados a uma classe social, a uma determinada etnia, a um determinado sujeito considerado "desviante" pelo padrão que é imposto. Desse modo, denunciamos esse processo de violação e violência e caminhamos para uma leitura sobre e com os movimentos que atuam pela transformação da realidade que os cerca e que de maneira alguma os/as agrada.

Paris (2015) compreende as Paradas LGBTQIAP+ como uma ação política e cultural que tem como principal objetivo a promoção da visibilidade de lésbicas, gays, bissexuais, travestis, transexuais, transgêneros, queer, intersexuais, assexuais e pansexuais. Dadas ações acontecem, principalmente, no espaço urbano através de sua ocupação ou da transformação de dinâmicas ocasionadas pela ação geralmente no período de um dia.

O conteúdo político da Parada reflete-se, principalmente, numa atitude contestatória e reivindicatória, abordando temas que perpassam a saúde, sexo, direitos humanos, desigualdade, cultura, etc. Ao mesmo tempo, a Parada, reflexo de uma ação política, também é vislumbrada como uma festa, assumindo um crítico caráter festivo que como bem postula Paris (2015), aproxima-se do lúdico e do carnavalizado.

A Parada LGBTQIAP+ representa uma ação de um ou vários movimentos socioespaciais e socioterritoriais e coletivos que levantam uma bandeira, assumem um compromisso que ora se aproximam do que pode ser compreendido como militância, a partir de quadros e estudos profundos acerca de determinado nicho, e ora de ativismo, a partir de ações pontuais, efêmeras e locais. Paris (2015, p. 11) pontua que "as paradas do Orgulho LGBTQIAP+, alavancadas por um formato considerado bem-sucedido pela militância, não só em São Paulo como também no Rio de Janeiro, expandiram-se de norte a sul do país, seguindo formato de ações similares".

O formato de ações similares expostos por Paris (2015) pode ser compreendido na forma como toda ação é preparada, bem como executada, são multidões que acompanham trios elétricos, bandeiras e decorações com as cores da diversidade, Drag Queen, militantes, partidos políticos, sindicatos e, em alguns casos, o setor privado. A participação dos diferentes movimentos socioespaciais e socioterritoriais possibilita de uma maneira mais explícita a capacidade que determinado evento e ação possui de aglutinar movimentos que tem como centralidade a conquista de territórios materiais e imateriais e movimentos que tem como centralidade a conquista de espaços a partir da elaboração de políticas públicas, etc.

Vale ressaltar que o aumento da visibilidade dessa população nos últimos anos, sobretudo, nas últimas duas décadas, decorre, sobretudo, das ações afirmativas e políticas públicas direcionadas a essa população. Dessa forma, Paris (2015, p. 14) retrata que "o período de 2010 a 2014 representa uma fase do 
Movimento LGBT, devido à implantação do Plano da Cidadania e Direitos Humanos LGBT pelo presidente Lula".

No século XIX, as relações afetivo-sexuais entre pessoas do mesmo sexo alteram-se de uma conotação e sentido pecaminoso, ou seja, de que tais práticas eram consideradas subversivas e pecados mediante a moral cristã, para doença e crime, através de códigos e leis que se agravavam pelo simples fato de um homem gostar de outro homem ou uma mulher gostar de outra mulher. Portanto, nos finais da década de 1960, surge nos Estados Unidos uma série de mobilizações e manifestações que ficaram conhecidas como "acontecimentos de Stonewall", sobre esse momento as "prisões arbitrárias eram comumente realizadas pela polícia local de forma a criar um clima de medo fomentando a prática da extorsão contra frequentadores de um bar gay" (Paris, 2015, p. 16).

Vale ressaltar que apesar de o Movimento em escala nacional e internacional ter avançado na despatologização, bem como no reconhecimento de suas identidades e orientações, ainda é possível observar movimentos conservadores ligados a extrema-direita que barram toda e qualquer tentativa de diálogo e discussão acerca da diversidade sexual e humana nos espaços de representação política, tendo em vista que a conhecida "Bancada da Bíblia" mais que dobrou desde 2016 segundo levantamento do Estadão. ${ }^{6}$

Um outro movimento importante nesse processo de disputas espaciais e territoriais (materiais e imateriais) é que nos últimos anos as Paradas se expandiram de forma exponencial, atingindo as mais variadas camadas da sociedade, bem como os espaços de socialização que agora acontecem desde as grandes metrópoles até as pequenas cidades, dos grandes centros aos bairros mais periféricos, reunindo pessoas numa manifestação de caráter efetivo, político e festivo.

Maia (2015) ressalta que as Paradas se constituem como uma importante festa popular nas cidades onde são realizadas. Dessa forma, explora a compreensão em torno da festividade contida na ação, bem como da não-festa, os elementos de confrontação política, contra a ordem, buscando compreender como acontece a territorialização nesses espaços. $\mathrm{Na}$ ala das manifestações representadas pelas Paradas é possível identificar também a existência de microterritórios e da disputa dos mesmos.

Além do caráter contestatório, a Parada LGBTQIAP+ já se tornou um evento de grande estrutura e complexidade, representando um papel significativo na economia das cidades que a realiza, como bem postula Vieira \& Costa (2014), quando trazem contribuições significativas a partir do impacto que a Parada proporciona nos meios hoteleiros, é crível que a Parada impacta os municípios economicamente. Dessa forma, também é importante compreender as mudanças e alterações ocorridas nas dinâmicas das cidades provocadas por sua ação.

${ }^{6}$ https://exame.com/brasil/bancada-da-biblia-mais-que-dobrou-desde-2006-mostra-levantamento/ 
Em termos geográficos, o Movimento LGBTQIAP+ é um objeto de estudo ainda em construção, ao mesmo tempo, já existem alguns materiais, sobretudo, de geógrafas feministas e autores LGBTQIAP+ que contribuem significativamente para uma leitura geográfica desses sujeitos ou de práticas congêneres. Dessa maneira, "essa correlação nos permite um primeiro entendimento: que os indivíduos buscam moldar o espaço à sua forma, ao passo que também se adaptam às condições dele" (Leite, Zanetti \& Toniolo, 2020, p. 15). Assim, veremos a partir das respostas dos sujeitos sociais, militantes e ativistas de movimentos socioespaciais e socioterritoriais que a Parada LGBTQIAP+ é um importante espaço em disputa pelos movimentos, instituições e organizações e partidos.

Inicialmente, apresentaremos algumas informações gerais que demonstram a qualidade da nossa amostra e possibilitam ao leitor um entendimento maior em torno do que produzimos e das relações que iremos estabelecer futuramente a partir das discussões lançadas partindo das Paradas, corpo e movimentos socioespaciais e socioterritoriais.

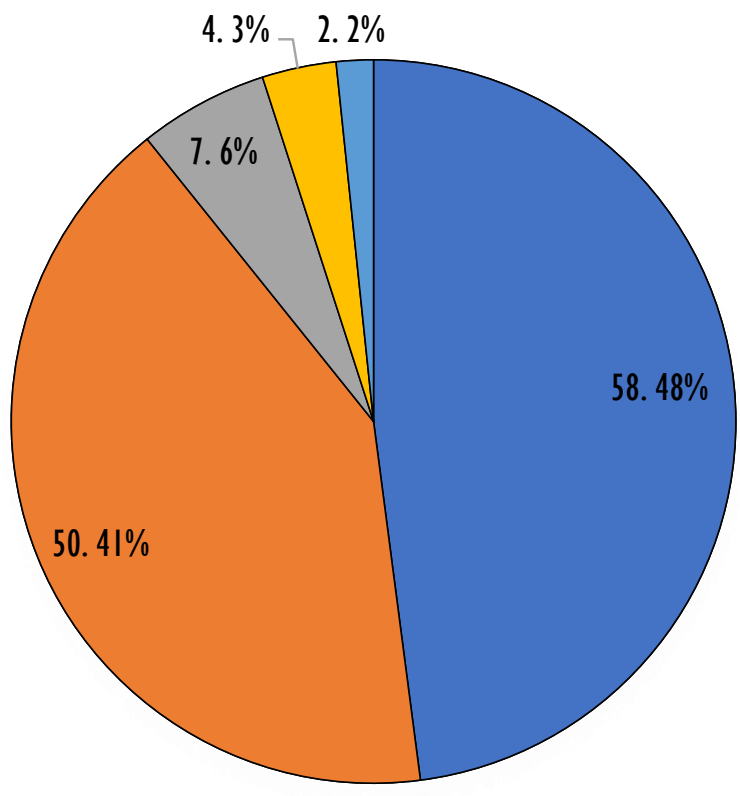

$\square$ Homem Cis $\square$ Mulher Cis $\square$ Homem Trans $\square$ Mulher Trans $\square$ Não-Binarie

Figura 2 - Gráfico relativo à identidade de gênero das pessoas que responderam ao questionário Fonte e Organização: Os autores, 2021.

Das pessoas que responderam ao questionário, 58 (48\%) são homens cis, 50 mulheres cis (41\%), 7 (6\%) homens trans, 4 (3\%) são mulheres trans e, por fim, 2 (2\%) pessoas se consideram como não-binarias.

Entende-se por cisgeneridade aquelas pessoas cuja identidade de gênero corresponde a que lhe foi atribuída ao nascimento. Entende-se por Transgeneridade aquelas pessoas que possuem uma identidade de gênero diferente daquela designada ao nascimento. Entende-se por uma pessoa não-binária aquelas 
identidades de gênero que não são nem masculinas, nem femininas, dessa forma, são pessoas que transitam e percorrem um caminho fora da lógica binária (homem e mulher).

Das pessoas que responderam ao questionário, 55 (45\%) são homossexuais, isto é, atraem-se por pessoas do mesmo gênero; 36 (30\%) consideram-se bissexuais, se orientam de forma afetiva, romântica e sexual para dois ou mais gêneros; 18 (15\%) consideram-se como heterossexuais, assim, atraem-se de forma afetiva, romântica e sexual por pessoas do gênero oposto ao seu; 9 (7\%) são pansexuais, consideram-se como pansexuais aquelas pessoas que se atraem por outras independentemente do gênero; 1 (1\%) consideram-se polissexuais, isto é, são pessoas que se atraem por vários gêneros, mas não por todos os gêneros e, por fim, duas pessoas que não informaram corretamente a sua orientação sexual.

Em relação a cor autodeclarada das pessoas que participaram do questionário, 66 (55\%) são brancas, 32 (26\%) consideram-se pardas, 21 (17\%) consideram-se pretas e $2(2 \%)$ consideram-se amarelas. Esse número evidencia a partir dos dados amostrais uma maior participação e acesso de pessoas brancas a esses espaços de promoção e visibilidade. Essa informação também se faz presente em outros trabalhos como de Ortolano (2015), que realiza uma leitura das características gerais dos participantes de algumas Paradas, como de São Paulo - SP e Campinas - SP.

Das pessoas que responderam ao questionário 51 (42\%) não possuem religião, 21 (17\%) são católicas, $15(12 \%)$ são ateus, $9(8 \%)$ se consideram espíritas, $9(8 \%)$ são umbandistas, 8 (7\%) são evangélicas, 4 (3\%) são candomblecistas, e, por fim, 1 pessoa da bruxaria, do budismo e ecumênico. A distribuição religiosa das pessoas que participaram do questionário é bem heterogênea, vale ressaltar o número expressivo de pessoas sem religião.

Tabela 1 - Distribuição da amostra em função da idade

\begin{tabular}{ccc}
\hline Faixa Etária & Número Absoluto & Número Relativo (\%) \\
16 a 30 & 87 & $71,9 \%$ \\
31 a 45 & 24 & $19,83 \%$ \\
46 ou mais & 10 & $8,26 \%$ \\
\hline Total & 121 & $100 \%$ \\
\hline
\end{tabular}

Fonte e Organização: Os autores, 2021.

A distribuição etária dos participantes (tabela 1) se dá, principalmente, entre 16 e 30 anos, agrupando um total de $87(71,9 \%)$ pessoas, seguido de 31 a 45 anos com $24(19,83 \%)$ pessoas e, por fim, 46 anos ou mais com $10(8,26 \%)$ pessoas participantes. Os dados demonstram uma participação expressiva de pessoas mais jovens em ações de promoção à diversidade, a exemplo da Parada e as semanas da diversidade. 
O questionário possui questões mais generalizantes e que demonstram alguns dados característicos de cada participante. Dessa maneira, consideramos relevante toda a informação levantada até aqui, visto que elas nos dão subsídios para uma leitura completa e geográfica desses sujeitos. As perguntas caminham dos aspectos mais generalizantes e, portanto, mais simples, até questões mais complexas que envolvem as práticas espaciais, a relação afetiva (ou não) com os espaços da cidade, o lugar como o espaço do pertencer, do sentir-se acolhido, enfim, uma série de informações que unem peça a peça e formam um quebra-cabeça geográfico acerca dos corpos e das vidas aqui expressas.

As próximas questões revelam dados e informações que assustam, mas que também nos direcionam para a informação geográfica e para a abordagem que conduz e sustenta essa pesquisa desde a abordagem geográfica em torno das Paradas LGBTQIAP+ realizadas em diferentes cidades do Estado de São Paulo, bem como as violências direcionadas a esses sujeitos.

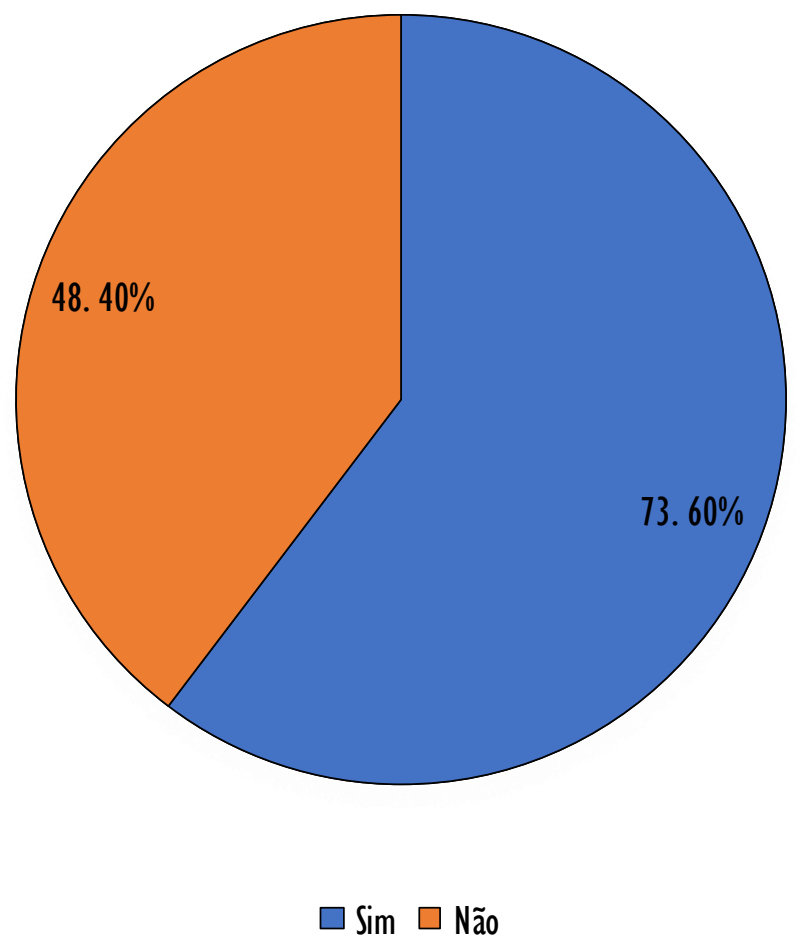

Figura 3 - Você já deixou de frequentar algum espaço por ser LGBTQIAP+? Fonte e Organização: Os autores, 2021.

Perguntamos aos participantes se em algum momento deixaram de frequentar algum espaço por serem LGBTQIAP+, 73 (60\%) revelam que já deixaram de frequentar algum espaço, 48 (40\%) apontam que nunca deixaram de frequentar algum espaço por esse motivo.

A maioria esmagadora das pessoas que participaram da pesquisa nos revela um dado que é, sobretudo, geográfico. O existir e ser "diferente" ou ser colocado no lugar do "diferente", do "exótico", do 
"queer" e por estar nessa condição/posição externaliza um receio em relação à utilização e o estar em determinados espaços. Dessa forma, é evidente que essas pessoas deixaram de frequentar ou estar pela condição "desviante" que apresentam e aparentam.

Ler, interpretar e avaliar todas estas condições impostas a corpos que não cabem, é também o papel da geografia brasileira, que somente nas últimas décadas tem se dedicado a este objeto, isto é, o corpo e suas espacialidades e territorialidades. Vemos surgir debates em torno do corpo como terceiro território (Fernandes, 2009), do corpo como escala geográfica, do corpo ora como espaço, ora como território, do corpo como expressão da vida, entre outras questões. É nessa mistura de conceitos e teorias em torno do corpo, que escrevemos e buscamos conectar conhecimentos já acumulados e novos conhecimentos a partir de outras bibliografias que facilitam a nossa interpretação em torno desse objeto, que mesmo não sendo 0 principal objeto desse manuscrito, cabe destaque e discussão. Nunes \& Rego (2011), observam que a corporeidade reconhecida como espacialidade, nos motiva e impulsiona ao entendimento de uma nova práxis, nesse novo cenário o corpo é percebido como resistência, afirmação e poder expresso nas relações sociais.

O corpo é a representação da nossa existência, das nossas vontades, intuições e mobilizações, o corpo é o instrumento que nos possibilita acessar os mais diferenciados espaços e territórios, "configura-se como nosso primeiro campo problemático e como escala geográfica elementar" (Nunes \& Rego, 2011, p. 87). Dessa forma, Nunes \& Rego (2011, p. 104), observam que as geografias do corpo são reivindicadoras de novas espacialidades, "exploram as relações do corpo com o espaço, do corpo com outros corpos e do corpo consigo mesmo".

Na primeira questão realizada, as pessoas que participaram do questionário já nos revelam uma informação interessante e que direta e indiretamente está ligada ao comportamento desses sujeitos no espaço urbano, bem como a organização que estabelecem em torno de lutas e ações de promoção a diversidade através da construção de territórios de resistência. 


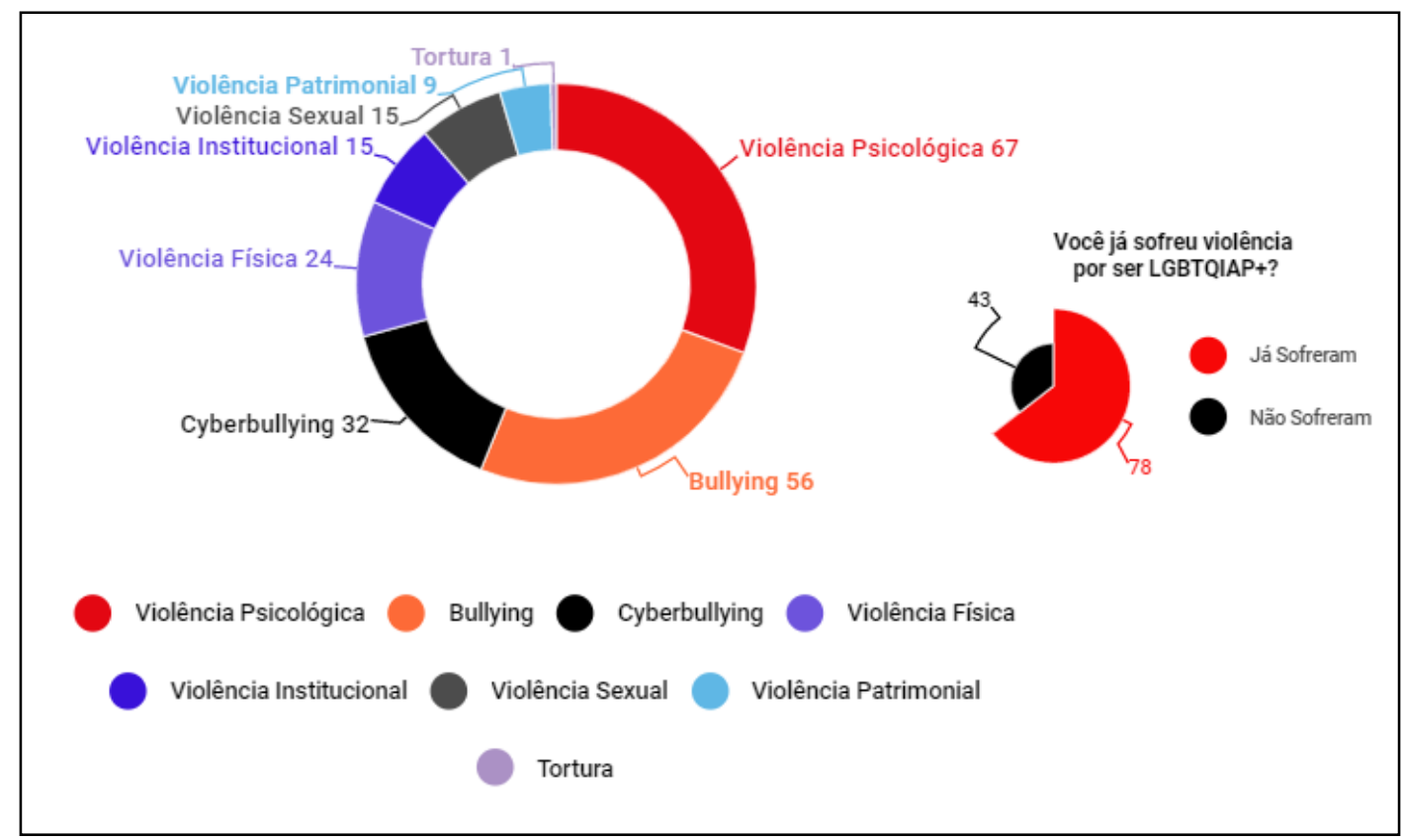

Figura 4 - Você já sofreu algum tipo de violência por ser LGBTQIAP+? Se sim, quais?

Fonte e Organização: Os autores, 2021.

Atrelada a informação anterior, temos os dados que evidenciam a violência em curso, bem como a sua continuidade e intensidade. Perguntamos as pessoas que responderam ao questionário se em algum momento de suas vidas sofreram algum tipo de violência por serem LGBTQIAP+. 78 (64,46\%) responderam que sim, 43 (35,54\%) responderam que nunca sofreram nenhum tipo de violência por serem LGBTQIAP+.

É possível observar a existência de vários tipos de violência, como: violência psicológica, bullying, cyberbullying, violência física, violência institucional, violência sexual, violência patrimonial e tortura. Vale lembrar que os entrevistados poderiam assinalar mais de um tipo de violência, isto é, uma única pessoa poderia concentrar todas essas violações; é por esse motivo que chegamos num número de violência sofridas superior ao número de pessoas que já sofreram algum tipo de violência.

O tipo de violência mais comum registrado entre as 78 pessoas que responderam sim para a pergunta, é a violência física, que se fez presente em 67 (30,59\%) relatos, seguida do bullying com 56 $(25,57 \%)$ relatos, cyberbullying com $32(14,61 \%)$, violência física comparece em 24 (10,96\%) dos relatos, seguida da violência institucional $15(6,85 \%)$ relatos, violência sexual também com 15 (6,85\%) relatos, violência patrimonial com $9(4,11 \%)$ relatos e, por fim, tortura com $1(0,46 \%)$ relato.

É possível observar com esses números que existe um processo de violência e violação de direitos básicos em curso. Tornamos claro inicialmente que algumas pessoas pelo fato de serem LGBTQIAP+ não frequentam ou deixam de frequentar espaços pelo medo da violência e por não se sentirem incluídos. Assim, o gráfico 4, torna explícita a quantidade de violências, bem como suas tipologias. 
É a partir da construção de valores bem fixados e estrategicamente construídos que a sexualidade vai sendo construída e reafirmada incessantemente, de forma hostil e sutil, o tempo todo ela é reafirmada, "meninos não se comportam assim", "meninas não sentam dessa forma", entre outras expressões que evidenciam a vigilância acompanhada da punição que regula, ao mesmo tempo que proíbe que aquele corpo se liberte do tido como "normal", assim, o que existe é "um trabalho pedagógico contínuo, repetitivo e interminável é posto em ação para inscrever nos corpos o gênero e a sexualidade 'legítimos'" (Louro, 2020, p. 16).

Das 121 pessoas que responderam ao questionário, 73 relataram terem deixado de frequentar algum espaço por serem quem são. A relação do não pertencer, do não frequentar e do não estar ali, nos revela a existência de territórios do medo, isto é, a não conformidade de um determinado território em relação a um determinado corpo. Quando um sujeito que não deveria estar ali segundo as lógicas existentes naquele território assim o faz, inicia-se um processo de violação, contínuo e permanente, que visa, sobretudo, a expulsão daquele corpo. Esse processo se dá em diferentes escalas da vida, como: na escola, na própria casa, no trabalho, na rua, na igreja, nos espaços de lazer, entre outros.

Existem espaços que não devem ser atravessados por corpos dissidentes, neles está contido o ódio a subversão, tido e posicionado como "desviante", neles está contido a violência e os processos de violação que, constantemente, impedem e perturbam corpos contra-heteronormativos de estarem ali. A construção de temáticas que cruzam o campo das sexualidades se intensificou consideravelmente nas últimas décadas, várias áreas e conhecimentos se dedicam constantemente a entender e a produzir materiais que facilitem a nossa compreensão em torno da questão da sexualidade, a geografia também se faz presente. Louro (2020), aponta que as entendidas "minorias sexuais" são entendidas equivocadamente como minoria numérica, quando na verdade representam uma maioria silenciosa, isto é, sujeitos que não tiveram acesso aos mesmos direitos que outros e por esse motivo foram colocadas em um lugar que não se sabe o nome, um espaço interdito. Dessa maneira, quando esses sujeitos se posicionam politicamente, transformam os guetos em territórios e ganham maior visibilidade. 


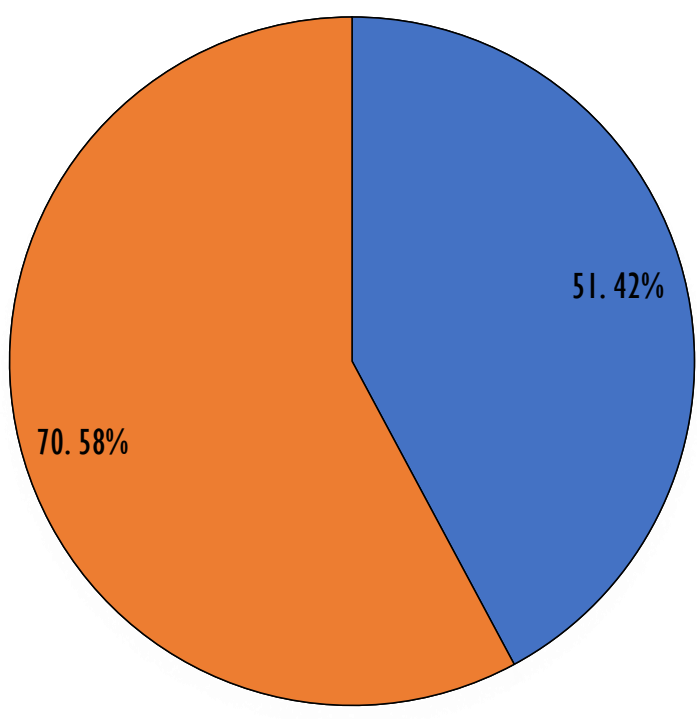

$\square \operatorname{Sim} \square$ Não

Figura 5 - Você faz parte de algum movimento social ou coletivo? Fonte e Organização: Os autores, 2021.

Das 121 pessoas que responderam ao questionário, 70 (58\%) não fazem parte ou integram movimentos socioespaciais e socioterritoriais e/ou organizações políticas, 51 (42\%) pessoas fazem parte de algum movimento social, coletivo, partido político e/ou associação. Dessa forma, identificamos uma participação política relevante das pessoas que responderam ao questionário, sendo elas importantes expoentes na luta contra a LGBTfobia e contra os processos de violação.

É possível identificar a participação em partidos políticos, movimentos socioespaciais e socioterritoriais, associações e organizações como: Partido Socialismo e Liberdade (PSOL), Corrente Socialista dos Trabalhadores (CST), Coletivo Capivara, Aliança Nacional LGBTI+, CRT, Associação da Parada do Orgulho LGBT (APOGLBT), Associação Prudentina de Prevenção a AIDS (APPA), Associação Amigos do Bairro do Jardim Tomé, Casa de Acolhimento LGBT (CASASSA), Coletivo Uyara (Grupo de Mulheres Criativas), Centro Acadêmico, Coletivos Feminista da Unesp, Coletivo Mandala, Associação de Transgêneros de Sorocaba, Coletivo Negro do Campus de São Paulo da Unifesp, Conselho LGBT, Partido dos Trabalhadores (PT), Família Stronger, Movimento de Cena Cultural, Frente Única de Cultura, Greenpeace, Grupo Somos LGBTI+, Identidade de Campinas - SP, Frente Brasil Popular (FBP), Juventude Petista, Levante Popular da Juventude (LPJ), Mães Pela Diversidade, Moradia Estudantil da UNESP, Povo Sem Medo, Partido Trabalhista Brasileiro (PTB) e Santo Útero. 
Os conceitos de espaço e território são caros e importantes para os movimentos sociais, assim, pensar como esses sujeitos organizados em diferentes esferas e setores da sociedade, se constitui enquanto um importante questionamento que nos leva para um aprofundamento do debate acerca dos movimentos sociais na geografia. É nesse sentido que Halvorsen, Fernandes \& Torres (2021) tecem uma discussão comparativa dos movimentos socioterritoriais.

Por que o espaço e o território são importantes para os movimentos sociais e como eles os produzem? Apesar da sempre aparente centralidade do espaço e do território - mediado e apropriado pelos movimentos sociais em todo o mundo (por exemplo: acampamentos de protestos, ocupações de terra, resistências indígenas, ocupações de terrenos e edifícios em áreas urbanas, organização de bairro e lutas por questões ambientais, pela educação, saúde, alimentos e outras políticas públicas, ativismos de mulheres, LGBTQIA+, feministas, estudantes, etc.), tem havido uma surpreendente falta de atenção a esta questão por estudiosos e estudiosas de várias áreas do conhecimento, por exemplo, geógrafos anglófonos em comparação com a extensa literatura sobre política contenciosa e lugar, escala e redes (Halvorsen, Fernandes \& Torres, 2021, p. 26).

O trabalho desenvolvido por Halvorsen, Fernandes \& Torres (2021) avança na reflexão sobre a ação dos movimentos socioterritoriais como uma categoria analítica que tem como objetivo central analisar a mediação do espaço e apropriação do território. Contrastam os conceitos de movimentos socioterritoriais, movimentos sociais e movimentos socioespaciais em quatro eixos de análise: 1) como o espaço e o território são produzidos como estratégia central para a realização dos objetivos de um determinado movimento, isto é, a partir de suas intencionalidades e objetivos que ordenam e reúnem um conjunto de estratégias expressas no espaço e território; 2) os espaços e os territórios produzem as identidades dos movimentos e geram novas subjetividades políticas; 3) o espaço e o território são lugares de socialização política que tecem novos valores e alteram conjunturas; 4) por meio dos processos de territorialização, desterritorialização e reterritorialização, os movimentos criam novas instituições.

É possível observar a existência de 31 organizações (movimentos socioespaciais e socioterritoriais) que concentram ao menos uma pessoa que pauta a diversidade sexual e de gênero. Dessa maneira, fica evidente a importância da participação política e da disputa realizada dentro dos coletivos, dos movimentos, partidos, associações, entre outros.

Tendo por enfoque demonstrar a relação geográfica, espacial e territorial das Paradas e das ações similares, restringimos a participação do questionário somente a pessoas que já participaram ou participam de ações como essas. Assim, buscamos entender as relações geográficas existentes nos movimentos, nos sujeitos (corpos) que compõem os movimentos, nas ideias provocadas e discutidas a partir destas ações, nas mudanças dinâmicas (espaciais, econômicas, políticas, culturais e sociais) provocadas por estas ações, bem como no impacto político que esse evento possui. 
Das 121 pessoas que responderam ao questionário, 91 (75\%) delas moram em cidades que realizam esse evento, ou seja, não necessariamente precisam se deslocar para outras cidades para prestigiarem 0 evento. É importante salientar, que esse movimento pode ser feito, existem pessoas que responderam ao questionário e que participam de diversas Paradas no Estado de São Paulo. Assim, o fato de o município realizar a ação não limita essas pessoas de frequentarem outras Paradas de outros municípios. 31 (25\%) pessoas responderam que o município em que moram não realiza a Parada ou qualquer ação similar a essa.

Exploramos ainda mais as respostas das pessoas que não possuem Paradas ou ações similares em suas cidades, queremos entender o que fazem e como fazem para participar destas ações, existe um deslocamento? Esse deslocamento gera um desconforto? Produz gastos? Como essas pessoas percebem as Paradas de outros municípios? Por que seus municípios não realizam ações como essa? Entre outras questões que ficarão explícitas no final deste tópico.

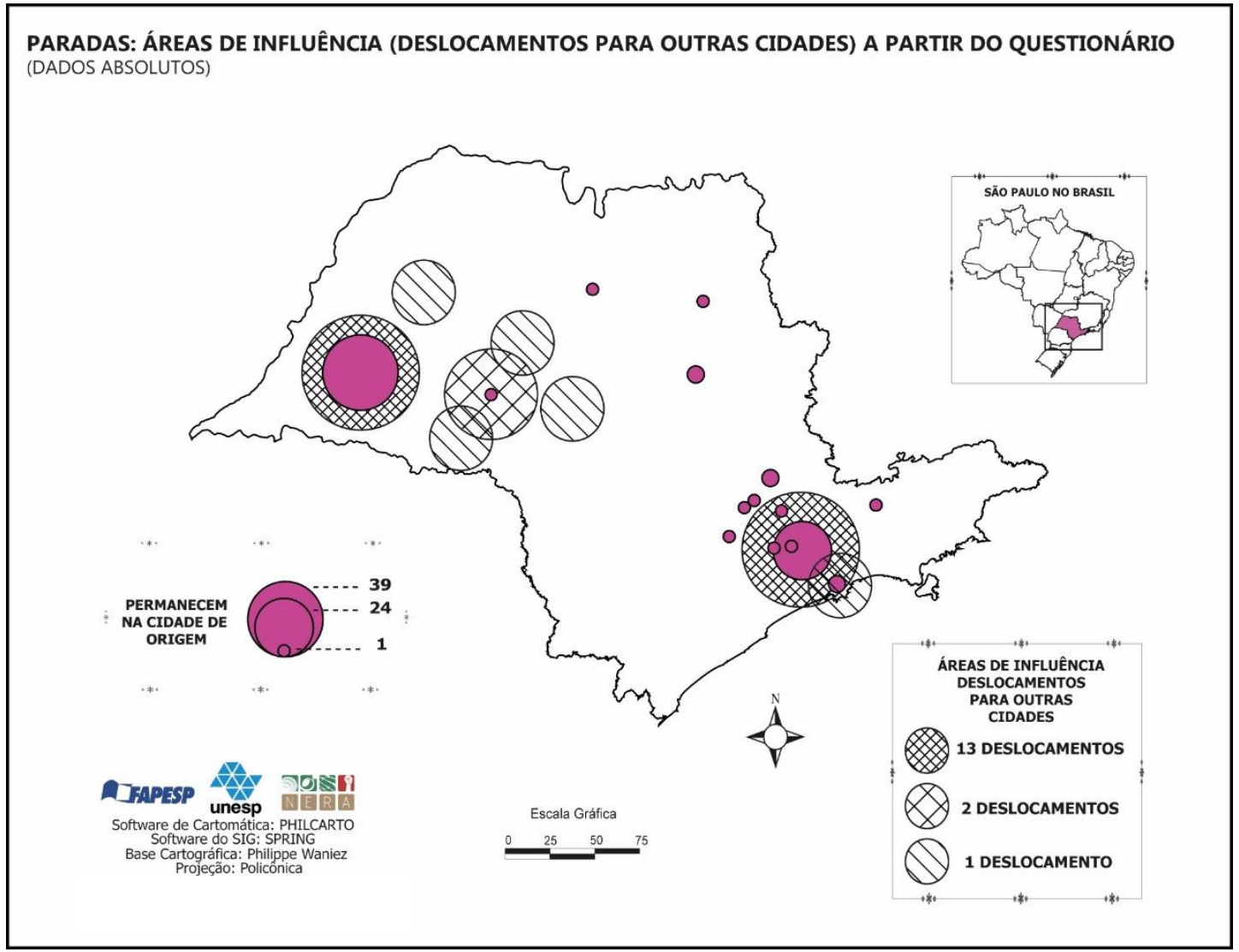

Figura 6 - Mapa relativo às áreas de influência (deslocamentos para outras cidades) a partir do questionário Fonte e Organização: Os autores, 2021.

Observamos a existência de uma relação hierárquica entre algumas Paradas do Estado de São Paulo a partir do questionário e do mapa (Figura 6).

1) Observação: as pessoas que possuem Paradas em seus municípios também se deslocam ou eventualmente participam de outras Paradas em outras cidades que possuem uma expressividade similar ou 
maior que a sua cidade, assim, é comum pessoas de Presidente Prudente - SP, cidade que realiza a Parada há aproximadamente 14 anos, deslocarem-se para outras cidades como Londrina - PR, Maringá - PR, São Paulo - SP, isto é, cidades que reúnem um número expressivo de pessoas na data da ação e que também possuem uma dinâmica mais intensa.

2) Observação: os dados colhidos a partir da aplicação dos questionários nos revelam uma informação importante, a existência de algumas áreas que desempenham um papel de influência, seja para o deslocamento de pessoas que não possuem Paradas em suas cidades, seja para as primeiras construções de Paradas e ações em municípios que ainda não a realizaram, essa movimentação torna explícito uma dinâmica a partir das redes de movimentos e ações coletivas que são criadas em torno dos mais diferenciados objetivos.

3) Observação: a partir das 121 respostas identificamos, sobretudo, 7 áreas de influência, é claro que se a nossa amostragem fosse maior e tivéssemos sujeitos de todos os municípios teríamos uma informação mais sólida e certamente mais áreas de influência. O que varia de uma área para a outra é o número de deslocamentos, isto é, quantas pessoas relataram o deslocamento para outras cidades para que assim pudessem participar da Parada.

0 mapa (Figura 6), torna explicita a existência destas 7 áreas de influência, duas delas concentram 13 deslocamentos cada: a região de Presidente Prudente - SP, localizada no extremo oeste do Estado de São Paulo e a cidade de São Paulo que exerce uma enorme influência nos municípios vizinhos, sobretudo, dos que não realizam a ação. É possível observar um deslocamento intenso para a cidade de Presidente Prudente - SP, esse deslocamento se dá pela realização da Parada e também pelo fato dessas outras cidades, sobretudo, do Oeste Paulista não realizarem essa ação.

Com relação ao aparato turístico utilizado pelas 31 pessoas que se deslocam para assistir e participar das Paradas de outras cidades, $23(74,19 \%)$ realizam esse deslocamento utilizando transporte público (ônibus, metrô e trem), 4 (12,90\%) realizam esse deslocamento a partir de fretamentos, isto é, aluguel de ônibus e carros, $3(9,68 \%)$ realizam o deslocamento a partir de excursões e, por fim, $1(3,23 \%)$ que desconhece qualquer aparato.

Em relação a ausência de ações como as Paradas nas cidades dos participantes que precisam se deslocar, $12(38,71 \%)$ dizem que a não organização se dá pela gestão municipal que se apresenta inflexível em torno das pautas LGBTQIAP+, 7 (22,58\%) apontam que o principal motivo é a falta de mobilização, da existência de coletivos, associações ou partidos, $4(12,90 \%)$ apontam que pelo fato das cidades serem pequenas a dinâmica não comporta ou impossibilita a realização deste evento, assim, é mais fácil prestigiar a ação e outras cidades que construir no seu município, 2 (6,45\%) apontam o preconceito como o principal problema e, por fim, $6(19,35 \%)$ não responderam a essa questão. 
Buscando explorar um pouco mais dos temas polêmicos que perpassam as Paradas e ações promovidas pelos movimentos e coletivos, demos um destaque espacial para dois conteúdos que coexistem na ação, a festa e a mobilização política.

É evidente que a Parada possui uma maneira específica de levantar e tratar alguns assuntos e temas, a primeira delas é a festa como uma mobilização, isto é, a capacidade que todo o aparato que é construído tem de atrair público e conquistar as pessoas. O segundo ponto é que além de ser uma festa mobilização, é também uma ação essencialmente política, ou seja, levanta e aborda temas que perpassam a vida e a existência de lésbicas, gays, bissexuais, transgêneros, queer, intersexuais, assexuais e pansexuais. A grande questão, como aponta a bibliografia, é o desequilíbrio dessas ações, o fato de em alguns momentos serem mais festivas do que política desagrada a uns e o fato de em alguns momentos serem mais políticas do que festivas desagradam a outros. Assim sendo, questionamos as pessoas que participaram do questionário se consideravam a Parada como uma ação festa, $96(79,34 \%)$ das pessoas que responderam consideram a Parada como uma festa, $25(20,66 \%)$ não consideram uma festa.

Além de provocar uma discussão acerca da Parada como uma festa, como uma manifestação ou como as duas coisas juntas, evidenciamos possíveis contradições, interpretações e equívocos. Assim, perguntamos as pessoas que participaram se consideravam a Parada como uma manifestação, 115 (95,04\%) responderam que sim, consideram a Parada como uma ação/manifestação política, 6 (4,96\%) pessoas responderam que não consideram a Parada como uma manifestação política. Dessa forma, é possível observar que o número de pessoas que não consideram a Parada como uma festa (25) é maior do que número de pessoas que não consideram esse evento como uma manifestação (6).

Perguntamos aos participantes se a Parada pode ser considerada como mais festa, mais manifestação ou se existe um equilíbrio entre as duas expressões contidas no evento. É possível observar que $50(42,02 \%)$ consideram a Parada como uma festa e também como uma manifestação, isto é, existe um equilíbrio entre essas duas expressões, $33(27,73 \%)$ pessoas consideram a Parada mais como uma festa e $33(27,73 \%)$ consideram mais como uma manifestação, $3(2,52 \%)$ pessoas não responderam a essa questão corretamente.

Perguntamos também se os participantes consideram que a Parada traz algum benefício pessoal. 109 (90,08\%) responderam que sim, que a Parada traz algum benefício pessoal, 12 (9,92\%) responderam que não consideram que a Parada traga algum benefício pessoal. Esse dado nos traz uma reflexão relevante, isto é, 109 pessoas que responderam ao questionário consideram a Parada como um evento que potencializa e beneficia suas vidas, direta ou indiretamente, isso significa que sentem e acreditam nessa ação como uma ferramenta de transformação da realidade. Em contrapartida, 12 pessoas não acreditam que a Parada traga 
algum benefício pessoal, entretanto, elas se consideram frequentadoras do evento, o que representa uma contradição.

Perguntamos as pessoas que responderam as questões sobre a possibilidade de a Parada acabar com o preconceito. 58 (46,77\%) pessoas responderam que talvez a Parada tenha o poder de acabar com 0 preconceito, $38(30,65 \%)$ consideram que ela não possui esse poder e, assim, não conseguirá por si só acabar com o preconceito e, por fim, $28(22,58 \%)$ responderam que sim, que ela possui a capacidade de acabar com o preconceito.

\section{CONSIDERAÇÕES FINAIS}

Os atos políticos que ocorrem nesse período em várias partes do mundo são centrais para o surgimento de novos espaços, que só foram produzidos a partir de um conflito (não norma x normatização dos corpos), ainda que alguns grupos reproduzam a heteronormatividade em seu cotidiano. Cabe destaque para as manifestações, as Paradas, as discussões promovidas em diferentes escalas que produzem não só um debate necessário dentro dos segmentos que representam a diversidade, mas em toda a sociedade, assim, é necessário refletir sobre os assuntos e temas que envolvem a diversidade sexual, consequentemente, a partir dessa reflexão se produz referências e avanços na compreensão do tema.

A Parada é tida pelo Movimento como um elemento central, que produz visibilidade, que constrói espaços de esperança e territórios de resistência, ela acolhe corpos que geralmente não ocupariam aquele espaço por medo da violência, de violações, do apedrejamento material e imaterial, assim, que espaço comporta o meu corpo?

A inscrição dos gêneros - feminino ou masculino - nos corpos é feita, sempre, no contexto de uma determinada cultura e, portanto, com as marcas dessa cultura. As possibilidades da sexualidade - das formas de expressar os desejos e prazeres - também são sempre socialmente estabelecidas e codificadas. As identidades de gênero e sexuais são, portanto, compostas e definidas por relações sociais, elas são moldadas pelas redes de poder de uma sociedade (Louro, 2000, p. 11). Na transitoriedade das construções das relações, dos afetos, dos desejos, apresentam-se a nós, diferentes outras realidades e possíveis experimentações. Da mesma forma é a sexualidade, entendida como um código impresso em nossos corpos, devemos - como nos foi imposto - apresentá-las e vivê-las de forma fixa, rígida e intransitiva, mas, na verdade, os pontos fixos se dissolvem e a fluidez é cada vez mais evidente e percebida espacialmente.

Logo, a partir dos sistemas de regulação as sociedades ditam o corpo que será aceito ou não, aquele que terá passe livre e aquele que será proibido de frequentar determinados espaços, aquele que será condecorado pela forma com que se apresenta e aquele que sofrerá diferentes punições por se apresentar de 
uma maneira diferente. A partir do exposto, podemos compreender o corpo como um importante componente do espaço geográfico, que numa apresentação carregada de símbolos e significados, modifica e é modificado pelas relações espaciais desempenhadas por dinâmicas e práticas espaciais corporificadas e generificadas.

O espaço como conceito chave para a interpretação das ações do movimento LGBTQIAP+ e também o corpo como uma escala geográfica viva e potente, nos possibilita leituras como essa, em torno das dinâmicas espaciais, das ações coletivas dos movimentos socioespaciais e socioterritoriais, dos processos de violação em curso, da construção de redes de movimentos e redes de esperança, entre outros temas e questões.

Verificou-se a partir desse artigo, que os movimentos socioespaciais, socioterritoriais, organizações, instituições e sujeitos organizados, ou não, de forma geral, entendem a Parada LGBTQIAP+ como um importante espaço de representação política em que a articulação e a construção de redes potencializam a constituição de políticas de acolhimento e cuidado. Observa-se que dada ação produz um sentimento de pertencimento, bem como a construção de sociabilidades e referências que contribuem para a emancipação desses sujeitos na escala individual e coletiva.

\section{REFERÊNCIAS}

Acetta, M. F. F. (2016). Gênero, sexualidade e práticas discursivas: escola, políticas públicas e produção de subjetividade. Dissertação (Mestrado), Universidade Federal do Rio de Janeiro, Rio de Janeiro, Brasil.

Aguião, S. (2016). "Não somos um simples conjunto de letrinhas": disputas internas e (re)arranjos da política "LGBT". Cadernos Pagu, (46), 279-310. Recuperado de

https://periodicos.sbu.unicamp.br/ojs/index.php/cadpag u/article/view/8645824

Amaral, J. G. (2014). Lutas por reconhecimento e heteronormatividade nas universidades, um estudo sobre os coletivos Universitários de Diversidade Sexual do Brasil. Dissertação (Mestrado em Ciência Política) Universidade Federal de Minas Gerais, Belo Horizonte, Brasil.

Bobbio, N. (2004). A Era dos Direitos. Rio de Janeiro: Elsevier.

Butler, J. (2003). Problemas de gênero. Rio de Janeiro: Civilização Brasileira.

Bianor, M. O. (2017). Reconhecimento das identidades de gênero sob uma perspectiva de direitos humanos: um ensaio sobre as identidades trans. Dissertação (Mestrado), Universidade Federal do Rio de Janeiro, Rio de Janeiro, Brasil.

Costa, B. P., \& Bernardes, A. (2013).

Microterritorializações homoafetivas na cidade de Presidente Prudente-SP: O lazer noturno e as relações de interface. Revista Cidades, 10(17), 30-60.

Fausto-Sterling, A. (2002). Dualismos em duelo. cadernos pagu, 17, 9-79.

Fernandes, B. M. (2009). Sobre a tipologia de territórios. In: M. A. Saquet \& E. S. Sposito (Eds.), Territórios e territorialidades: teorias, processos e conflitos. São Paulo: Expressão Popular, 197-215.

Foucault, M. (2001). História da sexualidade I: A vontade de saber. Rio de Janeiro: Graal.

Foucault, M. (1988). História da Sexualidade II: O uso dos prazeres. Rio de Janeiro: Graal.

Halvorsen, S., Fernandes, B. M., \& Torres, F. V. (2019). Mobilizing territory: socioterritorial movements in comparative perspective. Annals of the American Association of Geographers, 109(5), 1454-1470.

Halvorsen, S., Fernandes, B. M., \& Torres, F. V. (2021). Movimentos socioterritoriais em perspectiva 
comparada. Revista Nera, (57), 24-53. doi: https://doi.org/10.47946/rnera.v0i6.1460

Hirata, H., \& Kergoat, D. (2007). Novas configurações da divisão sexual do trabalho. Cadernos de pesquisa, 37, 595-609.

Hirata, H. (2008). Divisão-relações sociais de sexo e do trabalho: contribuição à discussão sobre o conceito de trabalho. Em Aberto, 15(65), 39-49.

Hirata, H. (2010). Mundialização, divisão sexual do trabalho e movimentos feministas transnacionais. Cadernos de crítica feminista, 80-107.

Hirata, H. S. (2015). Mudanças e permanências nas desigualdades de gênero: divisão sexual do trabalho numa perspectiva comparativa. Friedrich Ebert Stiftung Brasil.

Louro, G. L. (2018). Um corpo estranho: ensaios sobre sexualidade e teoria queer. Autêntica.

Leite, M., Zanetti, V., \& Toniolo, M. A. (2020). TERRITORIALIDADES LGBTs. Sociedade e Território, 32(1), 96-114.

Maia, C. E. S. (2015). Go West, in the Open Air: Parada do Orgulho LGBT Goianiense - da Repressão à Turistificação. Revista Latino-americana de Geografia e Gênero, (2), p. 200-221.

Marglin, S. (1980). Origem e funções do parcelamento das tarefas. Para que servem os patrões. Crítica da divisão do trabalho. São Paulo: Martins Fontes, 37-77.

Rego, N., \& Nunes, C. X. (2011). As geografias do corpo e a educação (do) sensível no ensino de geografia. Revista Brasileira de Educação em Geografia, 1(1), 86-107.

Ornat, M. J. (2008). Territórios da prostituição e instituição do ser travesti em Ponta Grossa - PR. 2008. Dissertação (Mestrado em Geografia), Universidade Estadual de Ponta Grossa, Ponta Grossa, Brasil.

Ornat, M. J. (2008). Sobre espaço e gênero, sexualidade e geografia feminista. Terr@ Plural, 2(2), 309.

Ortolano, Fábio. (2015). Concepções de sexualidade e direitos humanos: uma análise psicopolítica a partir das Paradas LGBT de São Paulo e Campinas. Dissertação (Mestrado em Ciências), Universidade de São Paulo, São Paulo, Brasil.

Paris, Gisele; (2015). Parada do Orgulho LGBT do Rio de Janeiro: um desfile-mobilização e suas estratégias comunicativas. Dissertação (Mestrado), Universidade Federal do Rio de Janeiro, Rio de Janeiro, Brasil.
Leite, M., Zanetti, V., \& Toniolo, M. A. (2020). Territorialidades LGBTs. Sociedade e Território, 32(1), 96-114.

Saffioti, H. (2005). Gênero e patriarcado. In: CastilloMartin M, Oliveira S, (Eds.), Marcadas a ferro. Brasília: Secretaria Especial de Políticas para as Mulheres, 3576.

Saffioti, H. I. B. (1976). A mulher na sociedade de classes: mito e realidade (Vol. 4). Vozes.

Souza, W., V., F., \& Feliciano, C. (2020). Mapeamento dos crimes de ódio contra LGBT: uma leitura socioespacial da violência entre os anos de $2017 \mathrm{e}$ 2018. Geografia em Atos (Online), 1(16), 121-140. doi: https://doi.org/10.35416/geoatos.v1i16.7283

Triviños, A. N. S. (1987). Introdução à pesquisa em ciências sociais: a pesquisa qualitativa em educação. São Paulo: Atlas.

Canindé G. V., F., \& Araujo Costa, M. L. (2014). A Parada do Orgulho LGBT no calendário de eventos da cidade e na geração de negócio para a rede hoteleira paulistana. Turydes, $7(16)$. 